\title{
АНАЛІЗ ЕКОЛОГО - АГРОХІМІЧНОГО СТАНУ ГРУНТІВ ХЕРСОНСЬКОЇ ОБЛАСТІ
}

\author{
В. Ільіна, К. Шпатар
}

Одеський державний екологічний університет

Ірунти Херсонської області недостатньо забезпечені гумусом, тому для отримання високих та стійких врожсаӥв иих культу необхідно застосування сучасних методів агрохімічної обробки, яка передбачає внесення хімічних заходів захисту рослин, мінеральних та органічних добрив. В рамках роботи виконано оцінку сучасного агроекологічного стану грунтів сільськогосподарського призначення, визначено основні характеристики, які впливають на рівень використання мінерального живлення рослинами. Погіршення еколого - агрохімічні характеристик грунтів призводить до погіршення якісних та кількісних характеристик отриманих на них врожаїв, що найбільш актуально в останні 20 років, у зв язку із значними змінами клімату, особливо на території Херсонської області. Аналіз основних характеристик грунту які визначають його еколого - хімічний стан, проводився за даними 2012 по 2016 років за всіма районами Херсонської області, тому отримана інформачія є сучасною і дозволяє використовувати ї̈ для надання практичних рекомендацій щзо до оптимізачії посівних площ та раціонального використання мікроелементів .

Ключові слова: еколого - агрохімічний стан, важкі метали, потенціал грунту, органічна речовина, вміст рухомих сполук.

Вступ. Ведення сільськогосподарського виробництва за умов застосування добрив, хімічних меліорантів та засобів захисту рослин не тільки не сприяє його продуктивності, але й призводить до деградації основного засобу виробництва в сільському господарстві грунту. Зростання кислотності грунтів, зменшення вмісту в них органічної речовини та елементів живлення, погіршення агрономіномічно важливих фізичних властивостей - це результат деградаційних процесів.

Проблема. Для цілей сільськогосподарського виробництва проблема оцінки еколого - агрохімічного стану грунтів є однію з найважливіших.

Аналіз останніх досліджень і публікацій. Питанням оцінки стану сільськогосподарських угідь займалась досить велика кількість науковців [1]. При цьому були ураховані основні грунтоутворюючі характеристики [2].

Мета досліджень. Виконати оцінку еколого - агрохімічного стану грунтів сільськогосподарського призначення Херсонської області, що дозволить надати практичні рекомендації що до оптимізації посівних площ основних сільськогосподарських культур, які культивуються на цій території.

Результати досліджень. Грунти Херсонської області відносяться до малогумусованих, середньородючих, тому, для отримання високих та стійких врожаїв сільськогосподарських культур необхідно використання органічних та 
мінеральних добрив, до складу яких входить велика кількість мікроелементів та важких металів . Особливо це актуально у зв'язку з тим, що ця територія відноситься до посушливої, з високим температурним фоном, недостатньою кількістю опадів, що викликає необхідність використання зрошення. Для більш детальної оцінки агроекологічних характеристик грунтового покриву Херсонської області, було виконано аналіз вмісту основних агроекологічних показників якості грунтів для цілей сільськогосподарського виробництва. На рисунку 1 наведено інформацію про вміст гумусу у грунтах сільськогосподарського призначення усіх районів Херсонської області у середньому за період з 2012 по 2016 роки. Аналізуючи наведений графік, робимо висновок, що найбільший зміст гумусу у Високопільському районі $(3,26 \%)$, а наменьший - у м. Нова Каховка $(0,95 \%)$ Середнє значення гумусу по області складає 2,3\%. Максимальний вміст гумусу відзначено у північних районах області, а мінімальний у центральних районах. У південній та центральній частинах області розташовані каштанові грунти, які відрізняються незначним вмістом гумусу, у північній та північно-східній частинах розташовані чорноземи південні, які мають вміст гумусу значно вищий, ніж каштанові.

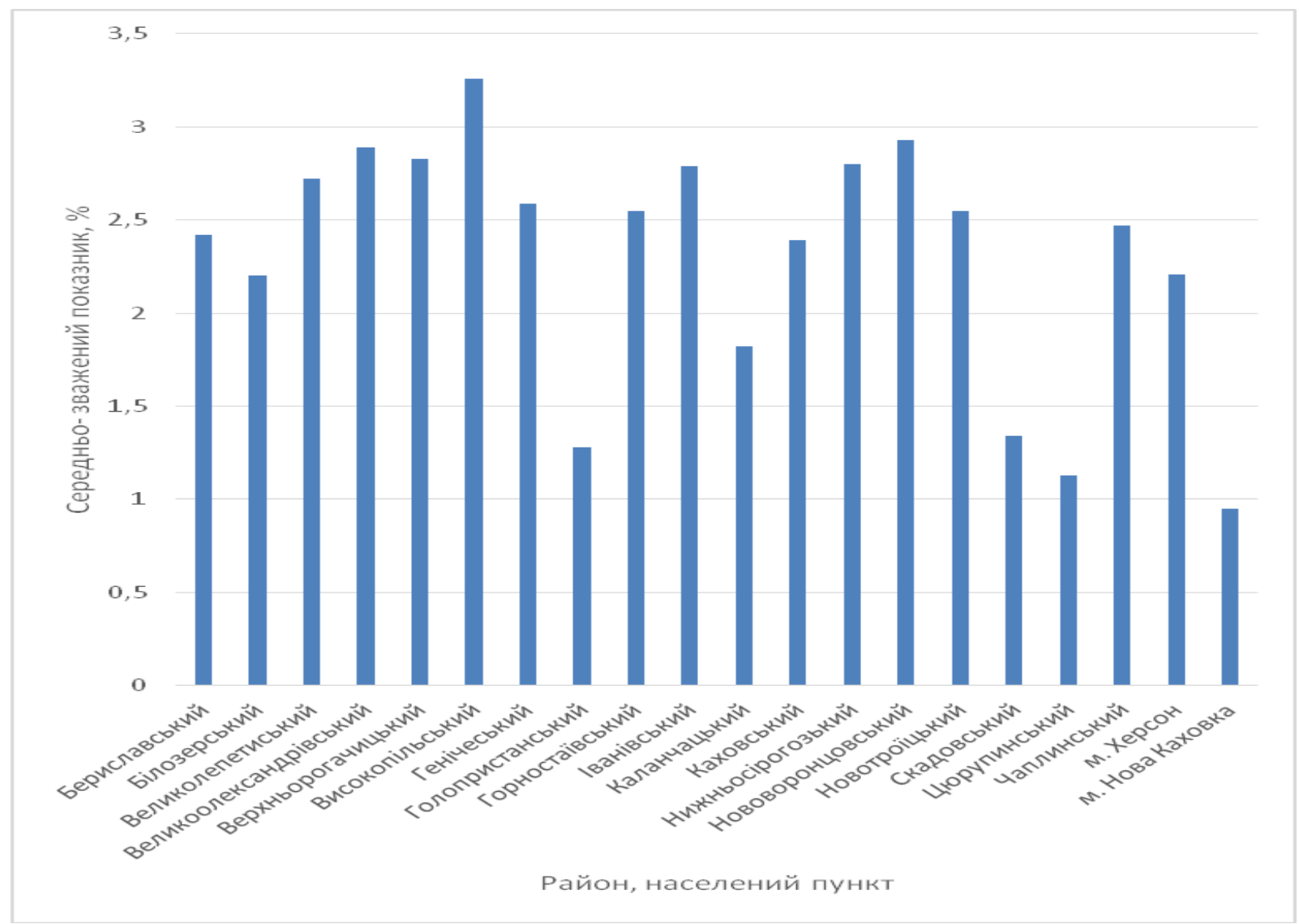

Рис.1. Характеристика грунтів за вмістом гумусу.

На рисунку 2 наведенахарактеристика грунтів за вмістом рухомих сполук, а саме фосфору, за методом Чирікова. Максимальне значення вмісту сполук фосфору спостерігалось у Каланчацькому районі, а мінімальне значення - у Верхньорогачинському. Середнє значення по області становить майже 143,2\%. 
По калію - мінімальні значення отримані у південно-західній частині, а максимальні у північних та східних районах області.

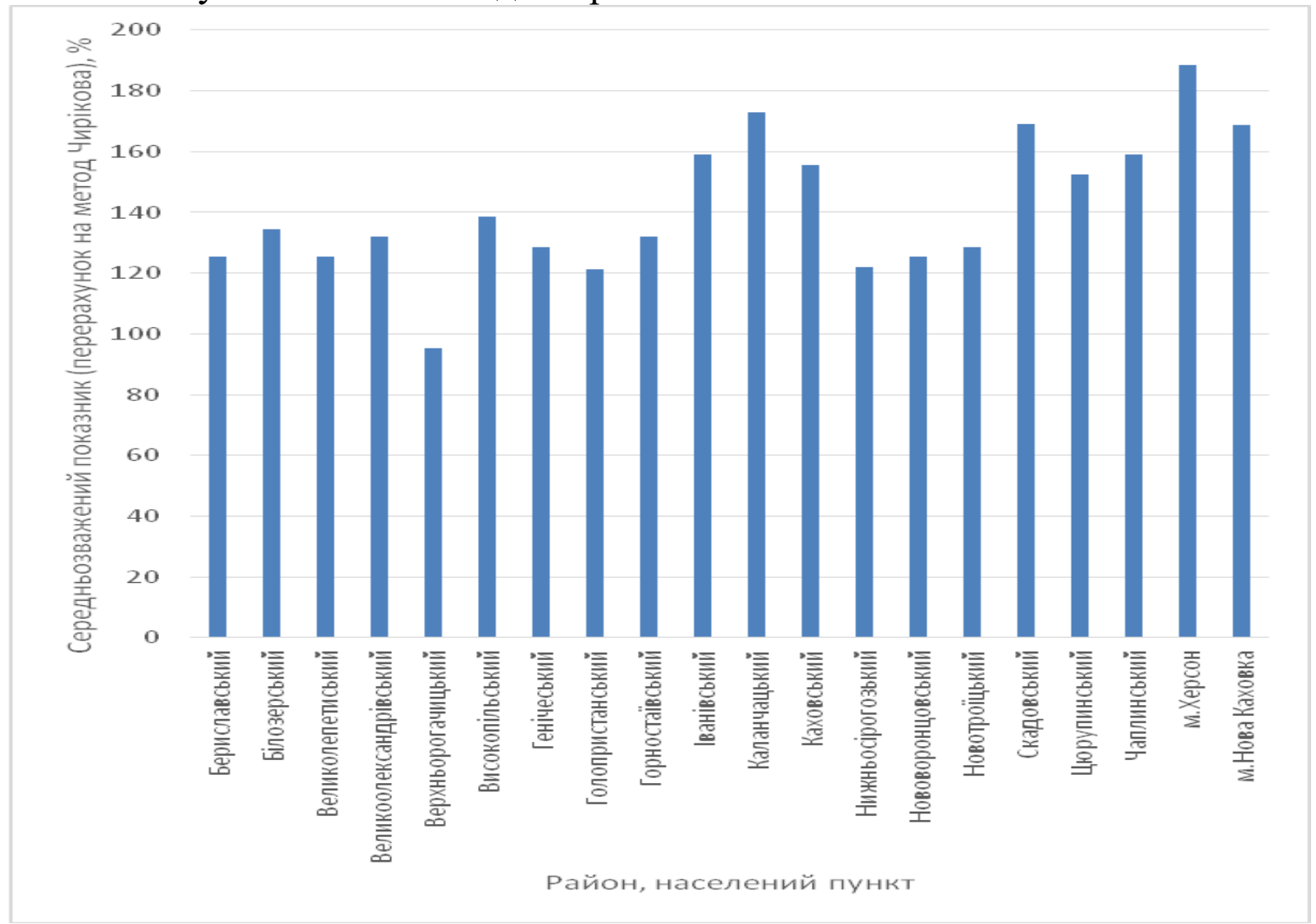

Рис.2. Характеристика грунтів за вмістом рухомих сполук фосфору.

На рисунку 3 представлено графік характеристики грунтів за вмістом рухомих сполук калію, за методом Чирікова. 3 графіку видно, що максимум спостерігався у Іванівському та Високопільському районах, а мінімум у Голопристаньському районі. Середнє значення по області складає майже 109мг/кг. У грунти Херсонської області відмічено значне внесення мінеральних добрив. Проаналізувавши вміст мікроелементів у грунтах сільськогосподарського призначення, зроблено висновок, що мінімальний вміст фосфору відзначено у Верхньорогачинському районі (північна частина), максимальні - у Каланчацькому районі.

В цілому, можна зробити висновок, що південні та центральні райони області зазнають значного антропогенного навантаження за рахунок внесення мінеральних добрив. У цих районах вирощують, такі сільськогосподарські культури, як просо, рис, овочі, які потребують великої кількості фосфорних добрив. У північних районах більшість площ зайняті під зернові та зернобобові культури, які менше виснажують грунт.

Другою складовою оцінки еколого - агрохімічного стану грунтів є оцінка вмісту важких металів, тому на рисунку 4 представлена динаміка забруднення грунтів Херсонської області важкими металами (рухлива форма). 
Agrarian Bulletin of tte Black Sea Littoral. 2020, Issue 97

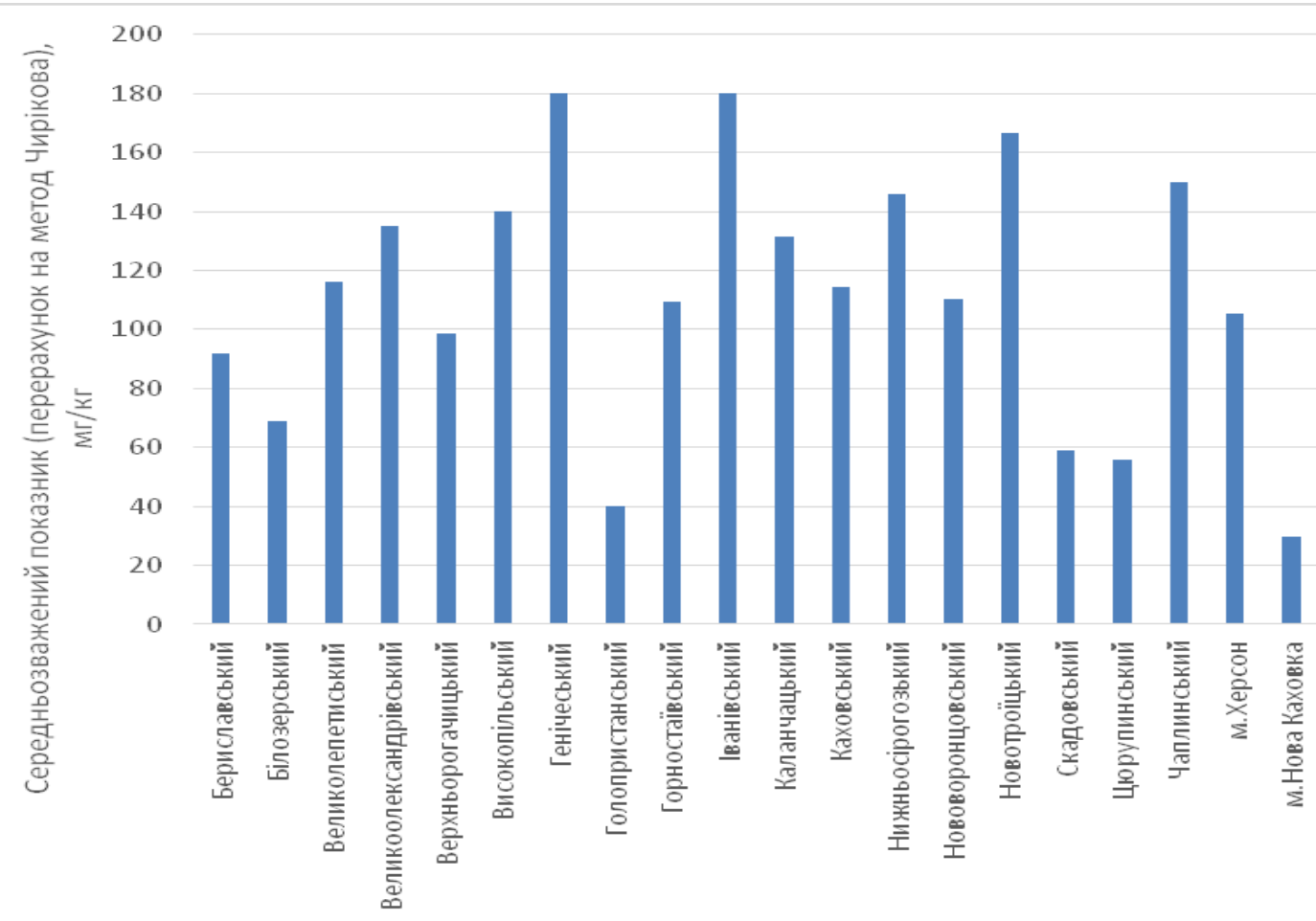

Район, населений пункт

Рис.3. Характеристика грунтів за вмістом рухомих сполук калію.

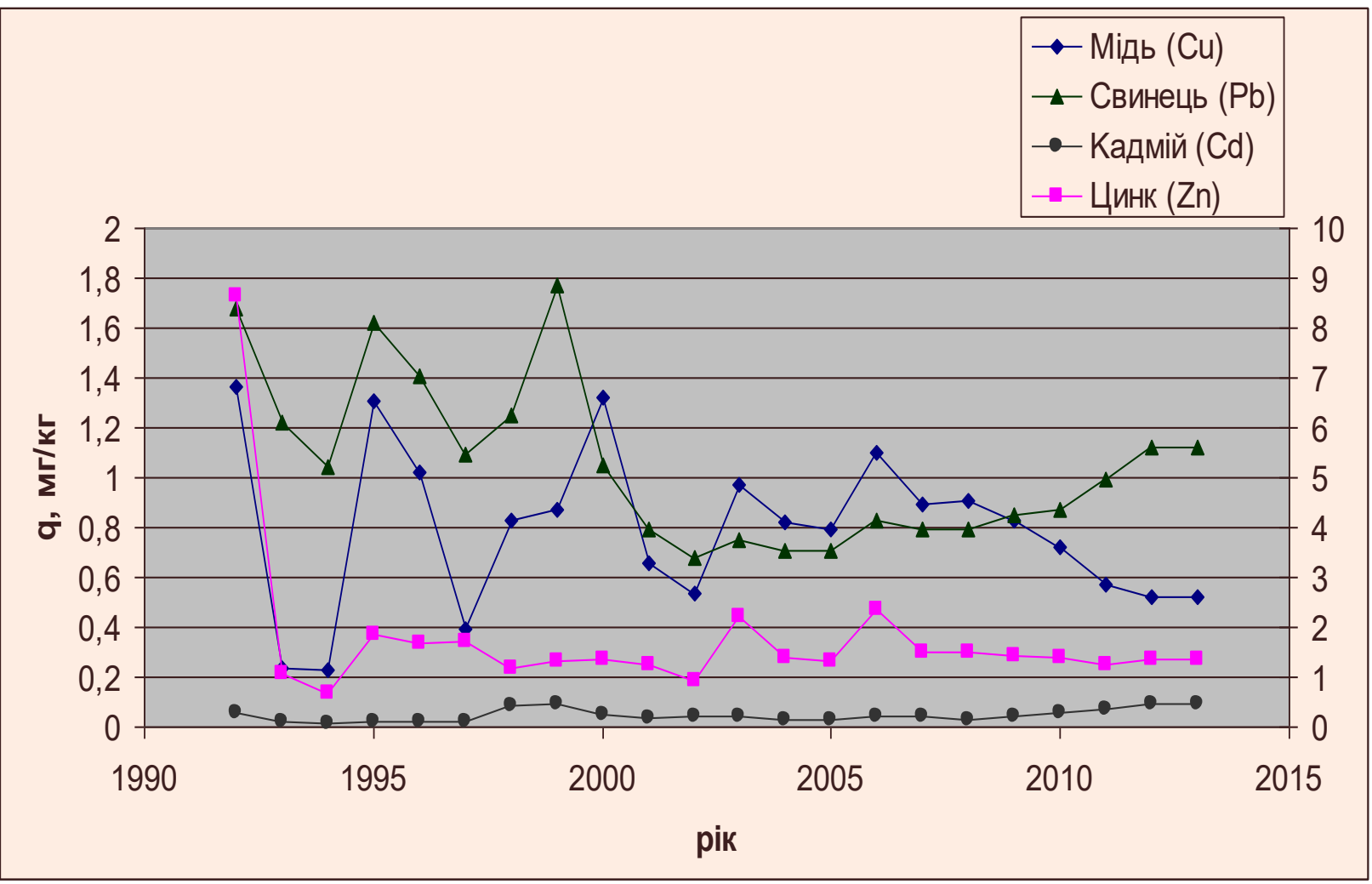

Pис.4. Динаміка забруднення грунтів Херсонської області важкими металами (рухлива форма).

Висновки. Аналізуючи графік, видно, що найбільше забруднення завдає свинець, а найменше - кадмій. Максимальні значення спостерігались в 1992 році - для міді і для цинку ( при цьому перевищень ГДК не спостерігалося, в 
1999 році - для свинцю і для кадмію ( перевищень також не було). За останні 10 років відзначено значне зменшення вмісту всіх важких металів практично у два рази. Це мабуть пов язано із зменшенням кількості мінеральних добрив у грунти та в цілому зменшення антропогенного навантаження на грунтовий покрив.

\section{ЛІТЕРАТУРА}

1. ДСТУ 4362:2004 Якість грунту. Показники родючості грунтів.Київ: Держспоживстандарт України, 2006. 19 с.

2. Татаріко О.Г. Бібліотека Всеукраїнської екологічної ліги.: Серія «Охорона навколишнього середовища», « Стан Грунтів України»// За ред. Київ: березень, 2005, №3 (15). 31 с.

\section{АНАЛИЗ ЭКОЛОГО - АГРОХИМИЧЕСКОГО СОСТОЯНИЯ ПОЧВ ХЕРСОНСКОЙ ОБЛАСТИ}

\section{Ильина В., Шпатар К.}

Почвы Херсонской области недостаточно обеспечены гумусом, поэтому для получения высоких и устойчивых урожаев этих культа необходимо применение современных методов агрохимической обработки, которая предусматривает внесение химических мер защиты растений, минеральных и органических удобрений. В рамках работы выполнена оценка современного агроэкологического состояния почв сельскохозяйственного назначения, определены основные характеристики, влияющие на уровень использования минерального питания растениями. Ухудшение эколого - агрохимических характеристик почв приводит к ухудшению качественных и количественных характеристик полученных на них урожаев, что наиболее актуально $в$ последние 20 лет, в связи со значительными изменениями климата, особенно на территории Херсонской области. Анализ основных характеристик грунта которые определяют его эколого - химическое состояние, проводился по данныл 2012 по 2016 годов по всем районам Херсонской области, поэтому полученная информация является современной и позволяет использовать ее для предоставления практических рекомендаций по оптимизации посевных площзадей и рацчионального использования микроэлементов.

Ключевые слова: эколого - агрохимическое состояние, тяжелье металль, потенциал почвы, органическое вещчество, содержание подвижных соединений.

\section{ANALYSIS OF ECOLOGICAL AND AGRO-CHEMICAL STATUS OF SOILS OF KHERSON REGION}

Ilina V., Shpatar K.

Soils of the Kherson region are insufficiently equipped with humus, therefore, to obtain high and stable crops of these crops, it is necessary to apply modern agrochemical methods, which include the introduction of chemical protection measures for plants, mineral and organic fertilizers. Within the framework of the work, an estimation of the modern agroecological state of agricultural soils has been made, the main characteristics that influence the level of mineral nutrition utilization by plants are determined. The deterioration of the ecological - agrochemical 
characteristics of soils leads to a deterioration of the qualitative and quantitative characteristics of the yields obtained on them, which is most urgent in the last 20 years, due to significant changes in the climate, especially in the Kherson region. The analysis of the main characteristics of the soil, which determine its ecological and chemical status, was carried out according to the data for 2012 through 2016 in all regions of the Kherson region, therefore the information received is up-to-date and allows it to be used to provide practical recommendations for optimizing crop areas and rational use of trace elements.

Key words: ecological - agrochemical state, heavy metals, soil potential, organic matter, content of mobile compounds. 